\title{
Representative Atmospheric Plume Development for Elevated Releases
}

\author{
PW Eslinger \\ HS Miley \\ JD Lowrey \\ AW Prichard \\ JI Mclntyre
}

February 2014

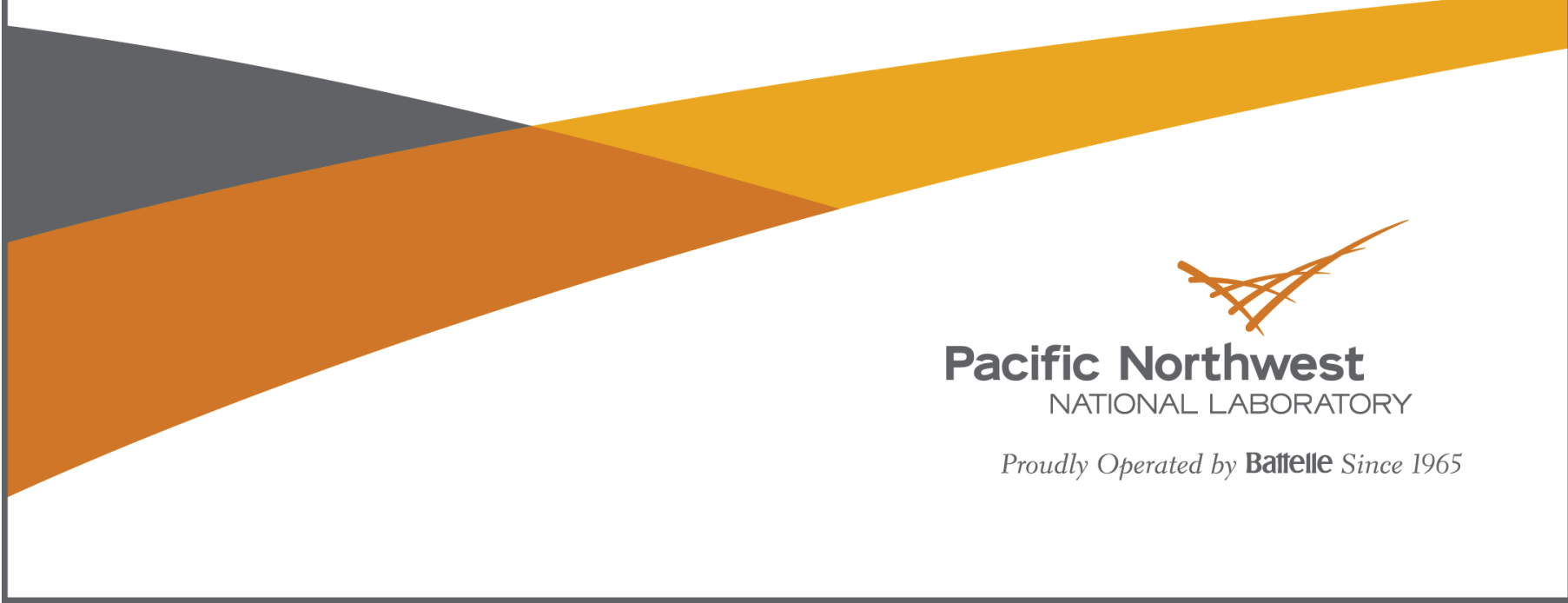




\title{
DISCLAIMER
}

This report was prepared as an account of work sponsored by an agency of the United States Government. Neither the United States Government nor any agency thereof, nor Battelle Memorial Institute, nor any of their employees, makes any warranty, express or implied, or assumes any legal liability or responsibility for the accuracy, completeness, or usefulness of any information, apparatus, product, or process disclosed, or represents that its use would not infringe privately owned rights. Reference herein to any specific commercial product, process, or service by trade name, trademark, manufacturer, or otherwise does not necessarily constitute or imply its endorsement, recommendation, or favoring by

the United States Government or any agency thereof, or Battelle Memorial Institute. The views and opinions of authors expressed herein do not necessarily state or reflect those of the United States Government or any agency thereof.

\author{
PACIFIC NORTHWEST NATIONAL LABORATORY \\ operated by \\ BATTELLE \\ for the \\ UNITED STATES DEPARTMENT OF ENERGY \\ under Contract DE-AC05-76RL01830 \\ Printed in the United States of America \\ Available to DOE and DOE contractors from the \\ Office of Scientific and Technical Information, \\ P.O. Box 62, Oak Ridge, TN 37831-0062; \\ ph: (865) 576-8401 \\ fax: $(865)$ 576-5728 \\ email: reports $a$ adonis.osti.gov
}

Available to the public from the National Technical Information Service

5301 Shawnee Rd., Alexandria, VA 22312

ph: (800) 553-NTIS (6847)

email: orders@ntis.gov $<$ http://www.ntis.gov/about/form.aspx>

Online ordering: http://www.ntis.gov

This document was printed on recycled paper.

$(8 / 2010)$ 


\title{
Representative Atmospheric Plume Development for Elevated Releases
}

\author{
PW Eslinger \\ HS Miley \\ JD Lowrey \\ AW Prichard \\ JI Mclntyre
}

February 2014

Prepared for

the U.S. Department of Energy

under Contract DE-AC05-76RL01830

Pacific Northwest National Laboratory

Richland, Washington 99352 


\section{Executive Summary}

An atmospheric explosion of a low-yield nuclear device will produce a large number of radioactive isotopes, some of which can be measured with airborne detection systems. However, properly equipped aircraft may not arrive in the region where an explosion occurred for a number of hours after the event. Atmospheric conditions will have caused the radioactive plume to move and diffuse before the aircraft arrives.

The science behind predicting atmospheric plume movement has advanced enough that the location of the maximum concentrations in the plume can be determined reasonably accurately in real time, or near-real time. Given the assumption that an aircraft can follow a plume, this study addresses the amount of atmospheric dilution expected to occur in a representative plume as a function of time past the release event. The approach models atmospheric transport of hypothetical releases from a single location for every day in a year using the publically available HYSPLIT code.

The effective dilution factors for the point of maximum concentration in an elevated plume based on a release of a non-decaying, non-depositing tracer can vary by orders of magnitude depending on the day of the release, even for the same number of hours after the release event. However, the median of the dilution factors based on releases for 365 consecutive days at one site follows a power law relationship in time, as shown in Figure S-1. The relationship is good enough to provide a general rule of thumb for estimating typical future dilution factors in a plume starting at the same point. However, the coefficients of the power law function may vary for different release point locations.

Effective dilution factors decrease more quickly following the release event in the case of radioactive decay than in a case based on a non-decaying tracer. An analytical expression for the dilution factors of isotopes with different half-lives can be developed given the power law expression for the non-decaying tracer. If the power law equation for the median dilution factor, $D f$, based on a non-decaying tracer has the general form $D f=a \times t^{-b}$ for time $t$ after the release event, then the equation has the form $D f=e^{-\lambda t} \times a \times$ $t^{-b}$ for a radioactive isotope, where $\lambda$ is the decay constant for the isotope.

* Median Power Law (Median)

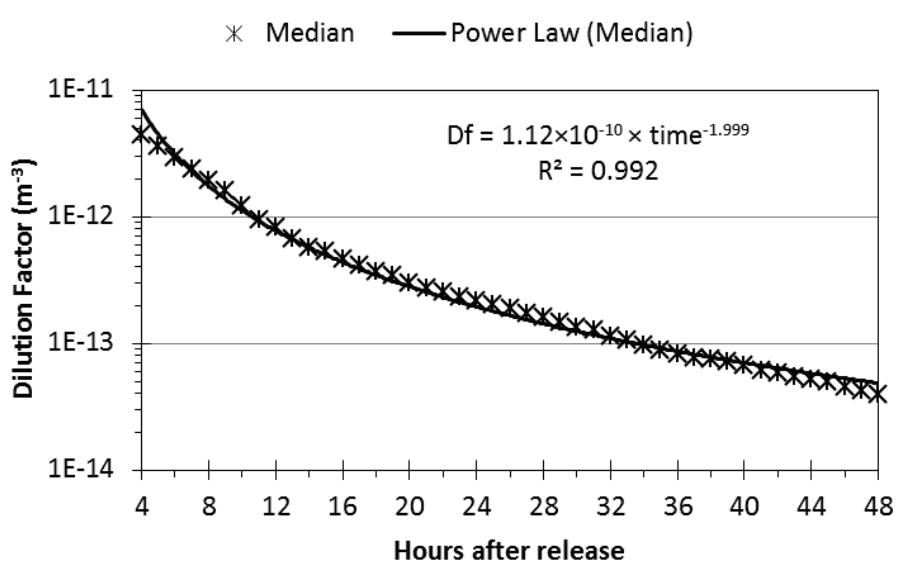

Figure S - 1. Median of maximum atmospheric dilution factors from 365 release events using a non-decaying tracer plotted with the best-fit power law trend-line as a function of time past the release event 



\section{Contents}

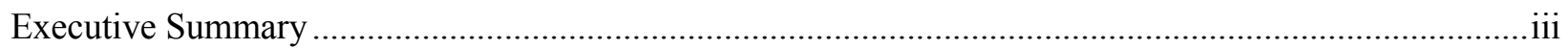

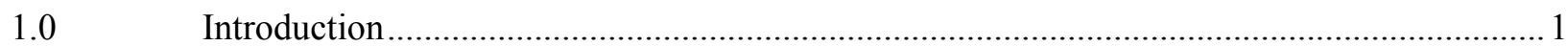

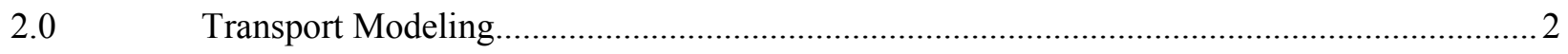

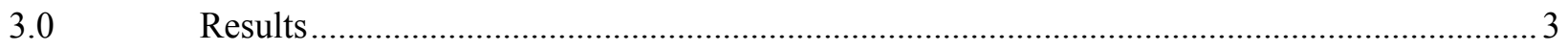

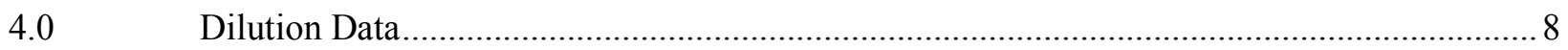

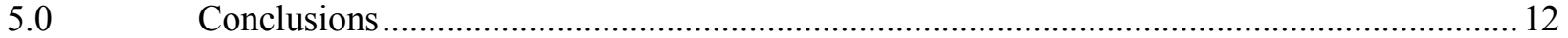

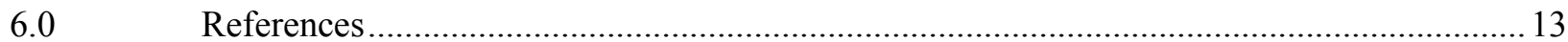




\section{Figures}

Figure S - 1. Median of maximum atmospheric dilution factors from 365 release events using a non-decaying tracer plotted with the best-fit power law trend-line as a function of time past the release event.

Figure 1. Atmospheric dilution factors at two elevations 42 hours after source release; run used meteorological data for August 1-3, 2011

Figure 2. Atmospheric dilution factors for the plume location with highest concentration as a function of time after release without radioactive decay

Figure 3. Median of atmospheric dilution factors from 365 release events plotted with the bestfit power law trend-line as a function of time after the release event.

Figure 4. Atmospheric dilution factors for the plume location with highest concentration as a function of time after release, decay-corrected for ${ }^{133} \mathrm{Xe}$.

Figure 5. Atmospheric dilution factors for the plume location with highest concentration as a function of time after release, decay-corrected for ${ }^{135} \mathrm{Xe}$.

Figure 6. Atmospheric dilution factors for the plume location with highest concentration as a function of time since release, decay-corrected for ${ }^{85 \mathrm{~m}} \mathrm{Kr}$..................................................

Figure 7. Atmospheric dilution factors for the plume location with highest concentration as a function of time since release, decay-corrected for ${ }^{88} \mathrm{Kr}$

\section{Tables}

Table 1. Noble Gas Isotopes and Their Half Lives .5

Table 2. Summary Statistics on the Dilution Factor Data before Application of Isotope-Specific Radioactive Decay 


\subsection{Introduction}

The atmospheric explosion of a low-yield nuclear device produces a large number of radioactive isotopes. Some of those isotopes can be measured with airborne detection systems. However, properly equipped aircraft may not arrive in the local region of the explosion for a number of hours after the event, by which time atmospheric conditions will have caused the radioactive plume to move and diffuse.

The science behind predicting plume movement has advanced enough that the location of the maximum concentrations in the plume can be determined reasonably accurately in real time or near-real time. Given the assumption that an aircraft can follow a plume, this study addresses the amount of dilution expected to occur in a representative plume as a function of time. The basic approach is to model hypothetical releases from a single location for every day in a year. Each release is modeled forward in time and the effective atmospheric dilution factors are collected and summarized. This work examines only the time evolution of effective atmospheric dilution factors; it does not address the ability to detect any specific isotope. Additional information on the magnitude of the release and the sensitivity of the measuring equipment is required to make detectability determinations. 


\subsection{Transport Modeling}

Isotopic atmospheric transport was modeled using the Hybrid Single Particle Lagrangian Integrated Trajectory (HYSPLIT) model, parallel version of February 2013, maintained by the U.S. National Oceanographic and Atmospheric Administration (Draxler and Hess 1998; Draxler et al. 2013). The transport runs were performed on a 168 compute-node Linux cluster.

The source location was set at $42^{\circ} \mathrm{N}$ and $93^{\circ} \mathrm{W}$, in the U.S. state of Iowa. The choice of location was arbitrary, but previous model runs performed for other purposes indicated that releases in this region had the potential to move thousands of kilometers within a few days. In order to account for seasonal differences, 365 transport runs were performed. Each run used archived meteorological data and started on a different day in 2011. The meteorological data (GDAS 2012) were defined on a $1^{\circ}$ global grid and have 3-hour time resolution. The transport also released a short duration unit-release of a non-decaying, non-depositing tracer at a point 2,500 $\mathrm{m}$ above ground level (AGL). The plumes were modeled for 50 hours past the time of release. The HYSPLIT code implements both a gridded advection-dispersion computational approach and a particle-tracking approach. For this analysis, the particle tracking approach was selected and each run used 2 million particles in order to achieve high-fidelity concentration solutions.

Concentration outputs from the HYSPLIT code are defined on a user-specified grid. For this analysis, concentrations were output at hourly intervals; the results for each hour represent the average for that hour. The output concentration grid was defined on a spacing of $0.1^{\circ}$ for both latitude and longitude, and at 24 evenly spaced levels between 2,000 and 8,000 $\mathrm{m}$ AGL for each point on the grid. Although concentrations above $8,000 \mathrm{~m}$ in elevation were not output, the top of the atmospheric model domain was set at 10,000 m AGL. Wet- and dry-deposition mechanisms were deactivated for the runs. Radioactive decay was not simulated in HYSPLIT, but it was applied as a post-processing step. 


\subsection{Results}

Example concentrations at two different levels are provided in Figure 1 for the model of a release using the meteorological data for August 1, 2011, and the following days. The plots below demonstrate concentrations 42 hours after the start of release. The concentrations in the top pane represent an average for elevations between 2,500 and 2,750 m AGL, with a maximum dilution of $8.5 \times 10^{-15} \mathrm{~m}^{-3}$. The bottom pane shows the averaged concentrations between 3,750 and 4,000 $\mathrm{m}$ AGL, with a maximum dilution of $3.8 \times 10^{-13} \mathrm{~m}^{-3}$. The portion of the plume at lower altitude has lower concentrations and is north of the region higher in the atmosphere where greater concentrations occur. The highest concentrations at this 42-hour mark occur about 1,000 km from the release point. For this time period, the effective top of the plume is $6,000 \mathrm{~m}$ AGL. This specific transport model illustrates a case in which the maximum plume concentration has risen above the initial release height.

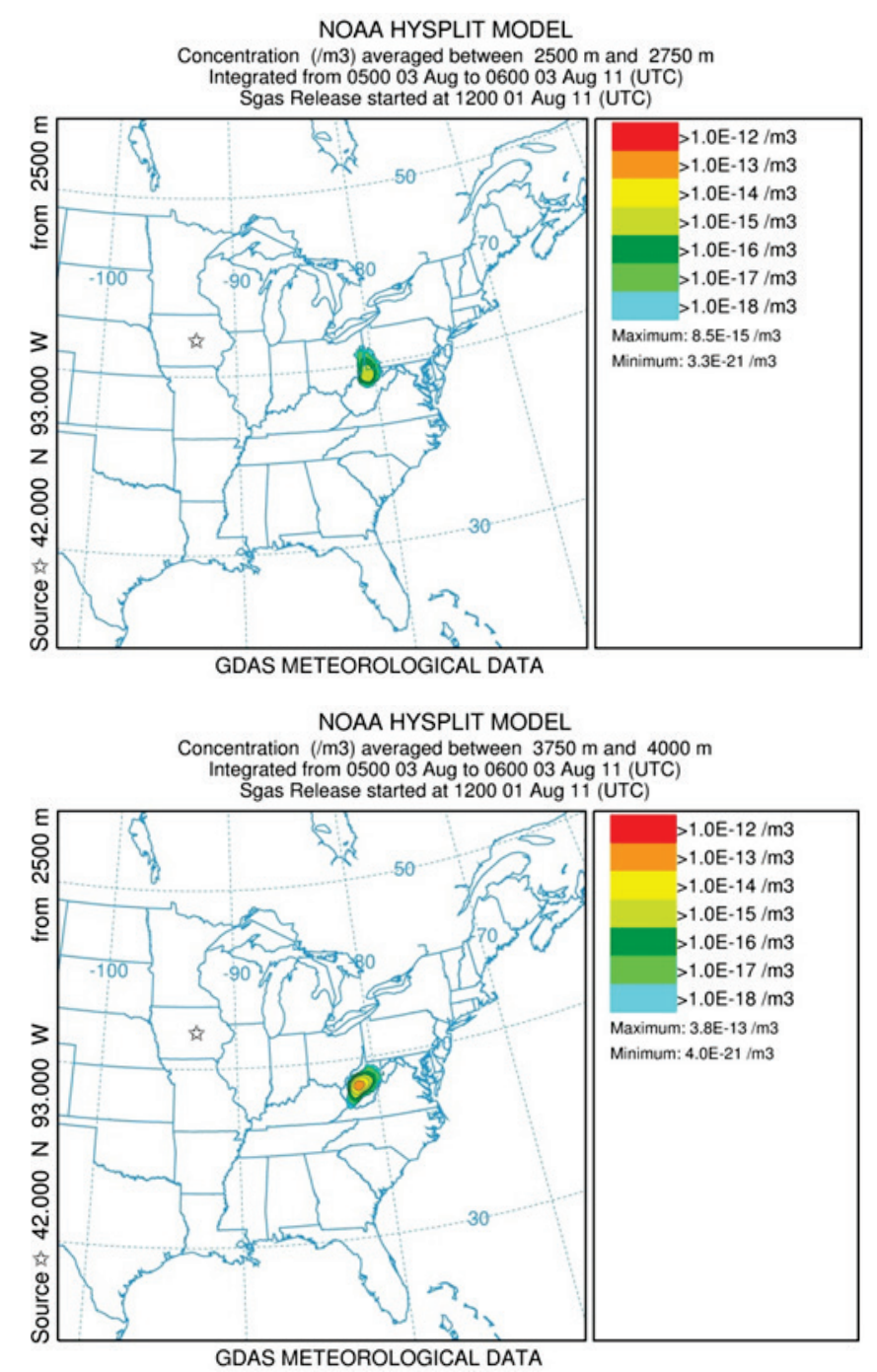

Figure 1. Atmospheric dilution factors at two elevations 42 hours after source release; run used meteorological data for August 1-3, 2011 
Effective dilution factors were calculated for every hour after the release for every run using information output by the HYSPLIT code. The dilution factor for the hour is associated with the place in the plume between 2,000 and 8,000 $\mathrm{m}$ AGL with the highest concentration that hour, given the unit release. Atmospheric transport of plumes can be quite complex. This definition allows the possibility that the maximum concentrations for succeeding hours can be significantly separated in horizontal distance or height above the ground. However, as illustrated in Figure 1, many of the plumes maintain a single lobe and in this case the location of the maximum concentration is within the relatively small lobe.

Summary results using the dilution factors without radioactive decay from the 365 model runs are presented in Figure 2. Averages and several dilution factor percentiles are presented. The example plume shown in Figure 1 falls almost on the average line in Figure 2. For this particular release location and archived meteorological data, the median dilution factor curve can be approximated using a power law trend-line. The median values and the trend-line are shown in Figure 3. The relationship is strong enough to provide a general rule of thumb for estimating typical future dilution factors in a plume. Although it is tempting to apply this trend-line to all potential release locations, modeling cases conducted for other activities suggest that trend lines for different release locations can be substantially different. Some of the differences are caused by the influence of trade winds, presence of mountainous terrain, or oceanic versus continental release sites.

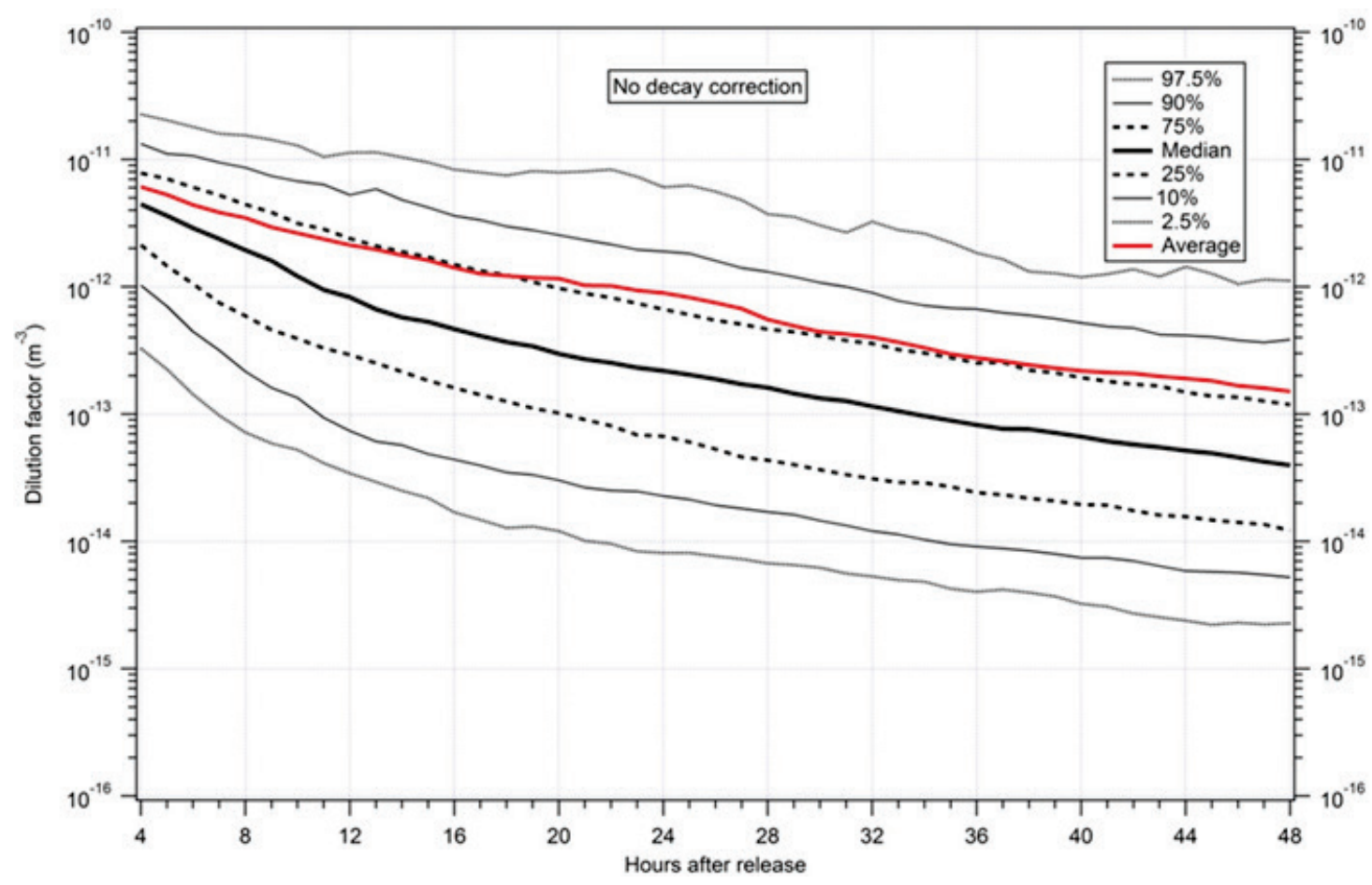

Figure 2. Atmospheric dilution factors for the plume location with highest concentration as a function of time after release without radioactive decay 


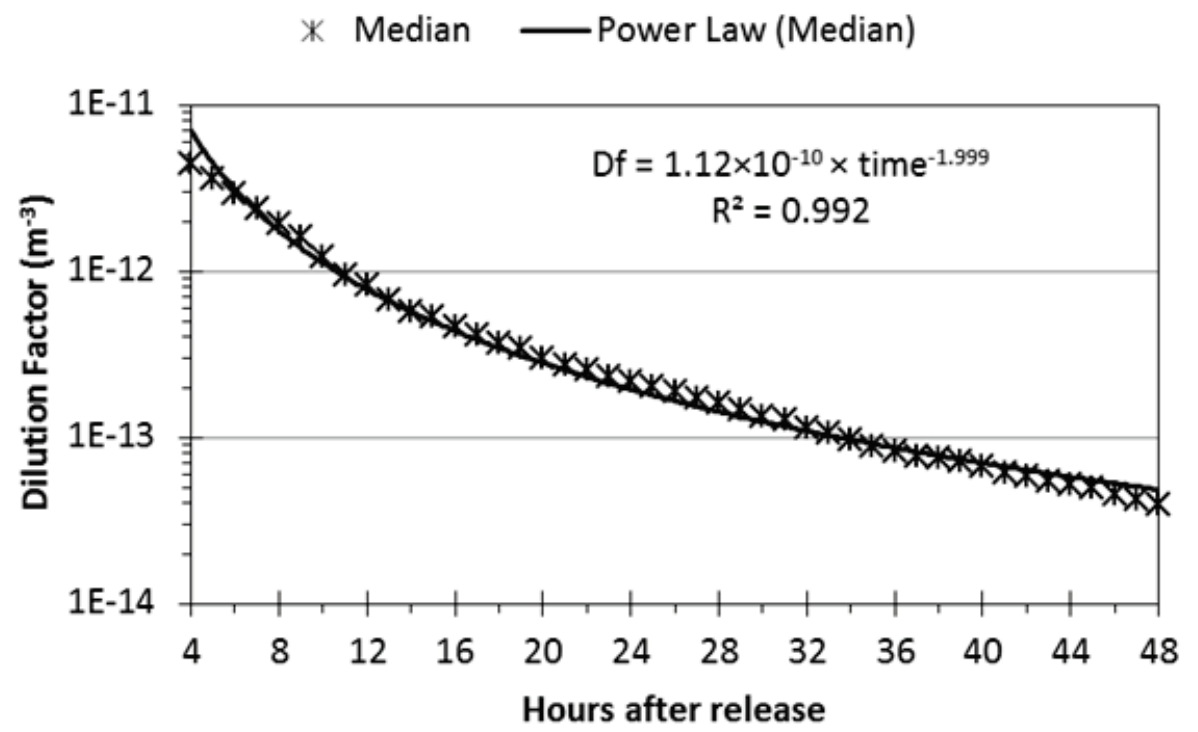

Figure 3. Median of atmospheric dilution factors from 365 release events plotted with the best-fit power law trend-line as a function of time after the release event

The atmospheric dilution factors in Figure 2 and Figure 3 are calculated without considering radioactive decay. Four noble-gas radionuclides produced in nuclear explosions are identified in Table 1.

Fortunately, deposition and rainout processes do not need to be included in the atmospheric transport runs for noble gases. The half-life values in Table 1 are taken from a website (Firestone 2014) maintained by staff members at Lawrence Berkeley National Laboratory. Effective dilution factors are provided in Figure 4, Figure 5, Figure 6 and Figure 7 for these four radionuclides. The vertical axes in Figure 4 through Figure 7 are dilution factors adjusted for the radioactive decay of the specific isotope.

Table 1. Noble Gas Isotopes and Their Half Lives

\begin{tabular}{c|cc}
\hline Isotope & Half-life (h) & Decay constant $\left(\mathbf{h}^{-\mathbf{1}}\right)$ \\
\hline${ }^{133} \mathrm{Xe}$ & 125.8 & 0.0055085 \\
${ }^{135} \mathrm{Xe}$ & 9.14 & 0.0758367 \\
${ }^{85 \mathrm{~m}} \mathrm{Kr}$ & 4.48 & 0.1547204 \\
${ }^{88} \mathrm{Kr}$ & 2.84 & 0.2440659 \\
\hline
\end{tabular}

If the power law equation for the median dilution factor, $D f$, based on a non-decaying tracer has the general form $D f=a \times t^{-b}$, then the equation has the form $D f=e^{-\lambda t} \times a \times t^{-b}$ for a radioactive isotope, where $\lambda$ is the decay constant for the isotope. The time units for $t$ and $\lambda$ in this equation are hours and inverse hours. Thus, dilution factors based on atmospheric transport runs for a non-decaying tracer can be used to develop the dilution factors for other isotopes. 


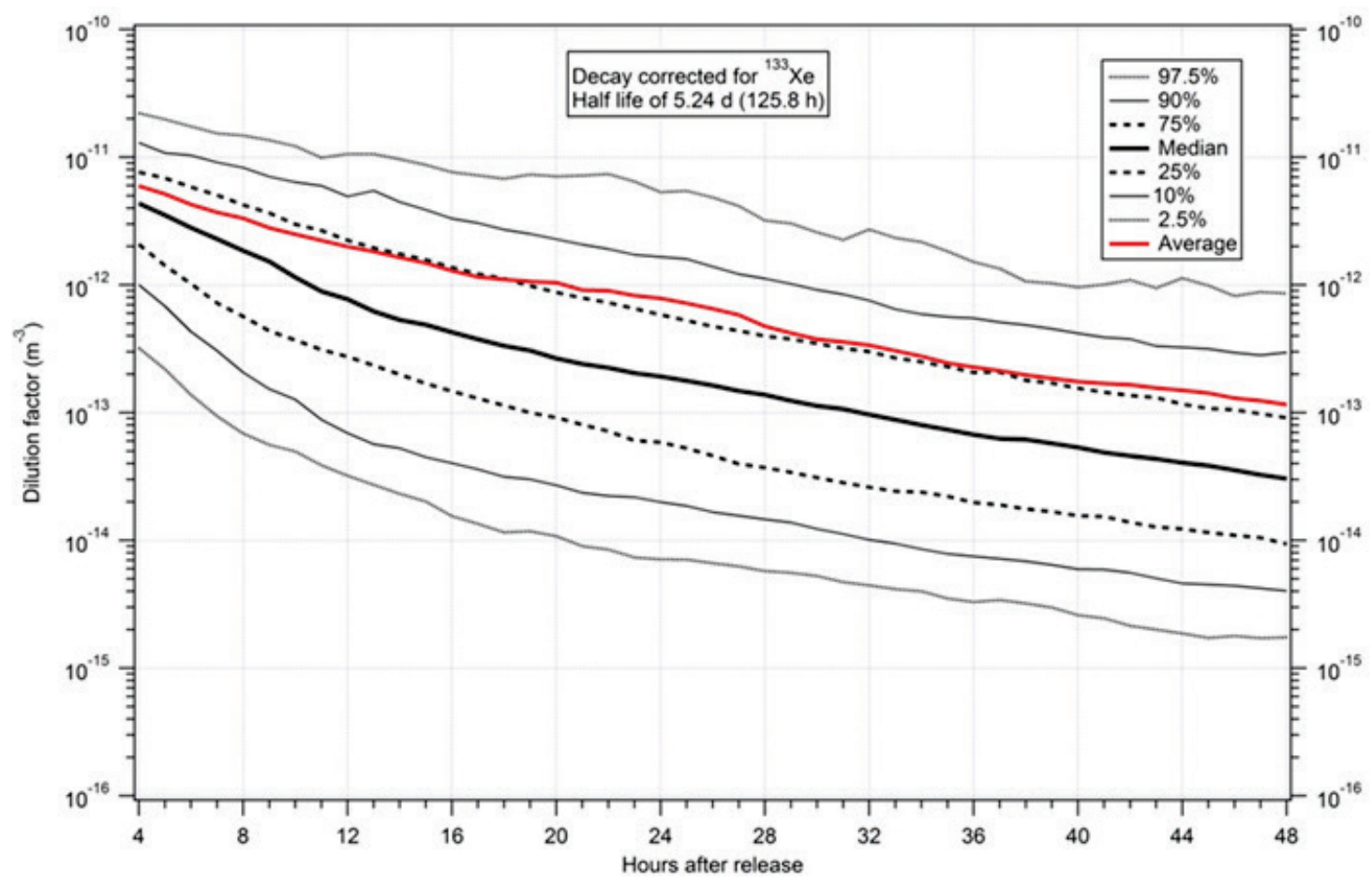

Figure 4. Atmospheric dilution factors for the plume location with highest concentration as a function of time after release, decay-corrected for ${ }^{133} \mathrm{Xe}$

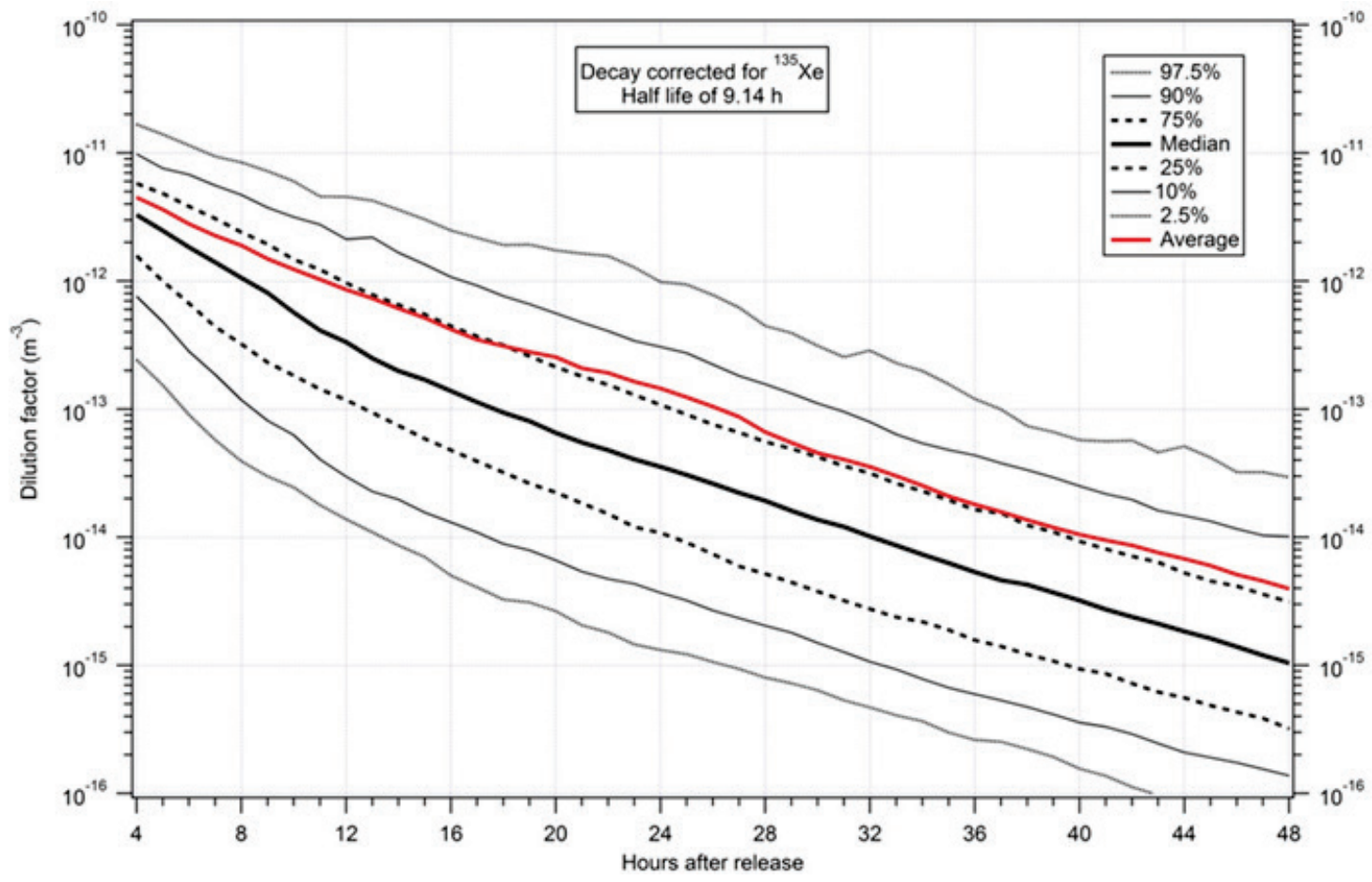

Figure 5. Atmospheric dilution factors for the plume location with highest concentration as a function of time after release, decay-corrected for ${ }^{135} \mathrm{Xe}$ 


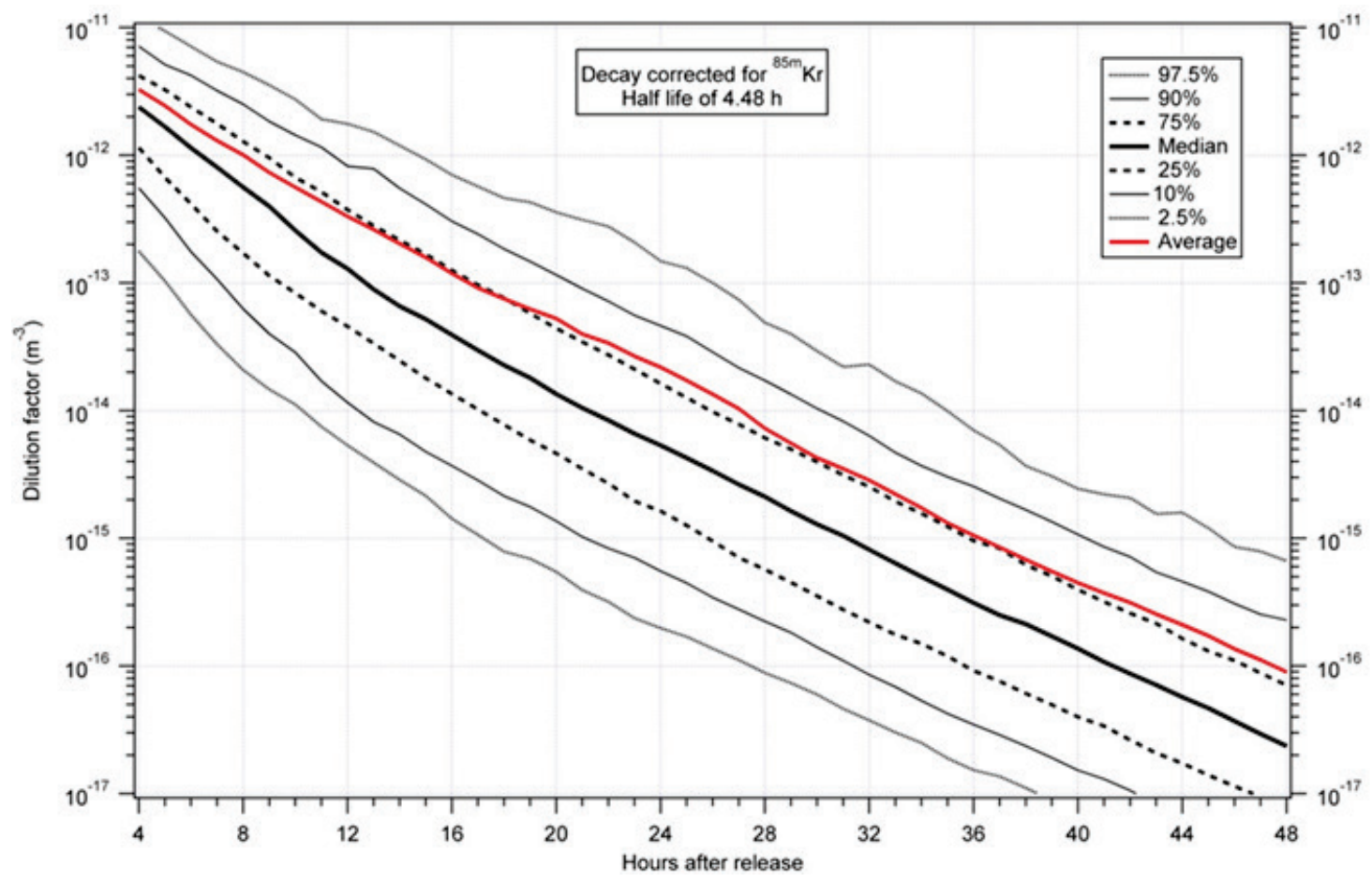

Figure 6. Atmospheric dilution factors for the plume location with highest concentration as a function of time since release, decay-corrected for ${ }^{85 \mathrm{~m}} \mathrm{Kr}$

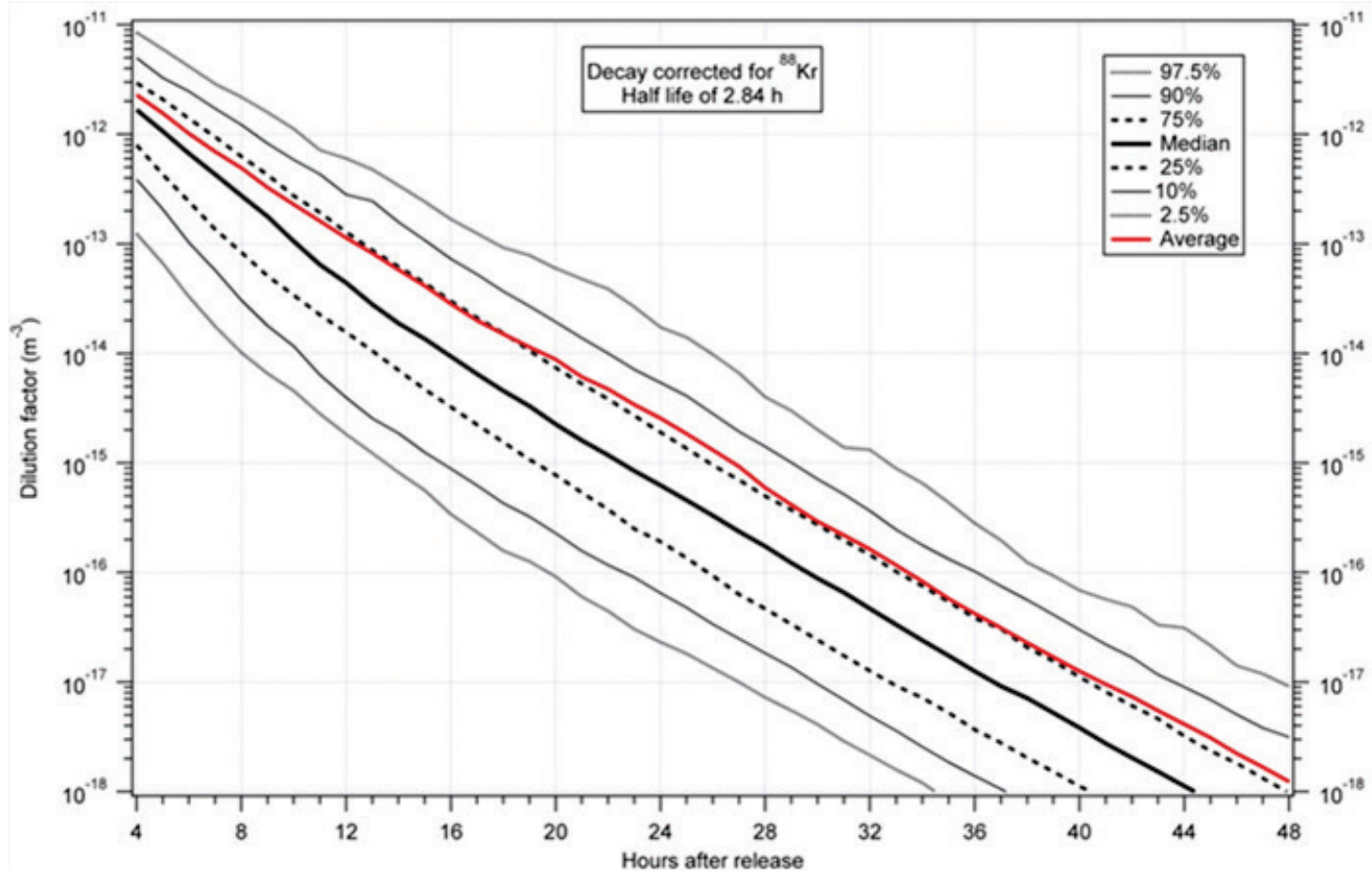

Figure 7. Atmospheric dilution factors for the plume location with highest concentration as a function of time since release, decay-corrected for ${ }^{88} \mathrm{Kr}$ 


\subsection{Dilution Data}

Summary statistics on the dilution factors from the suite of 365 data runs are provided in Table 2 . The data are presented before modification for radioactive decay, and as dilution factors as a function of time, thus they can be adjusted for decay for any isotope by multiplying by the time-dependent decay correction for that isotope. The multiplicative time-dependent decay correction can be expressed as $e^{-\lambda t}$, where $t$ is the number of hours past release and $\lambda$ is the decay factor for the specific isotope with units of $h^{-1}$. 
Table 2. Summary Statistics on the Dilution Factor Data before Application of Isotope-Specific Radioactive Decay

\begin{tabular}{|c|c|c|c|c|c|c|c|c|c|c|c|c|}
\hline Hour & Average & St. Dev. & Minimum & $2.5 \%$ & $10 \%$ & $25 \%$ & Median & $75 \%$ & $90 \%$ & $95 \%$ & $97.5 \%$ & Maximum \\
\hline 1 & $6.352 \mathrm{E}-12$ & 3.385E-12 & $1.825 \mathrm{E}-12$ & $2.243 \mathrm{E}-12$ & $3.148 \mathrm{E}-12$ & $3.875 \mathrm{E}-12$ & $5.586 \mathrm{E}-12$ & $8.021 \mathrm{E}-12$ & $1.091 \mathrm{E}-11$ & $1.274 \mathrm{E}-11$ & $1.400 \mathrm{E}-11$ & $2.264 \mathrm{E}-11$ \\
\hline 2 & 8.047E-12 & $6.550 \mathrm{E}-12$ & 5.619E-13 & $1.484 \mathrm{E}-12$ & $2.281 \mathrm{E}-12$ & $3.813 \mathrm{E}-12$ & $6.138 \mathrm{E}-12$ & $1.055 \mathrm{E}-11$ & $1.571 \mathrm{E}-11$ & $2.124 \mathrm{E}-11$ & $2.574 \mathrm{E}-11$ & $4.329 E-11$ \\
\hline 3 & $6.915 \mathrm{E}-12$ & $5.882 \mathrm{E}-12$ & $2.033 \mathrm{E}-13$ & $6.425 \mathrm{E}-13$ & $1.425 \mathrm{E}-12$ & $2.734 \mathrm{E}-12$ & 5.267E-12 & 8.938E-12 & $1.385 \mathrm{E}-11$ & 1.887E-11 & $2.239 \mathrm{E}-11$ & $3.898 \mathrm{E}-11$ \\
\hline 4 & $6.085 \mathrm{E}-12$ & 5.987E-12 & $1.146 \mathrm{E}-13$ & $3.286 \mathrm{E}-13$ & $1.027 \mathrm{E}-12$ & $2.128 \mathrm{E}-12$ & 4.444E-12 & $7.826 \mathrm{E}-12$ & $1.326 \mathrm{E}-11$ & $1.836 \mathrm{E}-11$ & $2.264 \mathrm{E}-11$ & $3.968 \mathrm{E}-11$ \\
\hline 5 & 5.294E-12 & 5.907E-12 & 7.985E-14 & $2.246 \mathrm{E}-13$ & 7.017E-13 & $1.455 \mathrm{E}-12$ & 3.620E-12 & $7.056 \mathrm{E}-12$ & $1.110 \mathrm{E}-11$ & $1.533 \mathrm{E}-11$ & 2.037E-11 & 4.324E-11 \\
\hline 6 & 4.407E-12 & 4.816E-12 & $6.889 \mathrm{E}-14$ & $1.429 \mathrm{E}-13$ & $4.456 \mathrm{E}-13$ & $1.056 \mathrm{E}-12$ & 2.897E-12 & $6.040 \mathrm{E}-12$ & $1.071 \mathrm{E}-11$ & $1.378 \mathrm{E}-11$ & $1.807 \mathrm{E}-11$ & 3.192E-11 \\
\hline 7 & $3.851 \mathrm{E}-12$ & $4.338 \mathrm{E}-12$ & $5.898 \mathrm{E}-14$ & $9.770 \mathrm{E}-14$ & $3.171 \mathrm{E}-13$ & 7.492E-13 & $2.381 \mathrm{E}-12$ & $5.242 \mathrm{E}-12$ & $9.489 \mathrm{E}-12$ & $1.287 \mathrm{E}-11$ & $1.600 \mathrm{E}-11$ & $3.108 \mathrm{E}-11$ \\
\hline 8 & $3.480 \mathrm{E}-12$ & 4.567E-12 & 4.776E-14 & 7.182E-14 & $2.161 \mathrm{E}-13$ & $5.911 \mathrm{E}-13$ & $1.942 \mathrm{E}-12$ & 4.425E-12 & 8.647E-12 & $1.210 \mathrm{E}-11$ & $1.548 \mathrm{E}-11$ & $4.201 \mathrm{E}-11$ \\
\hline 9 & $2.944 \mathrm{E}-12$ & 3.955E-12 & 3.873E-14 & 5.897E-14 & $1.611 \mathrm{E}-13$ & 4.592E-13 & $1.601 \mathrm{E}-12$ & $3.843 \mathrm{E}-12$ & $7.413 \mathrm{E}-12$ & $1.075 \mathrm{E}-11$ & $1.430 \mathrm{E}-11$ & $3.247 \mathrm{E}-11$ \\
\hline 10 & $2.638 \mathrm{E}-12$ & $3.894 \mathrm{E}-12$ & $2.959 \mathrm{E}-14$ & $5.246 \mathrm{E}-14$ & $1.342 \mathrm{E}-13$ & 3.917E-13 & $1.213 \mathrm{E}-12$ & $3.150 \mathrm{E}-12$ & $6.755 \mathrm{E}-12$ & $9.638 \mathrm{E}-12$ & $1.289 \mathrm{E}-11$ & $3.330 \mathrm{E}-11$ \\
\hline 11 & 2.373E-12 & 3.817E-12 & $2.321 \mathrm{E}-14$ & 4.117E-14 & $9.361 \mathrm{E}-14$ & 3.303E-13 & $9.477 \mathrm{E}-13$ & $2.836 \mathrm{E}-12$ & 6.357E-12 & $9.375 \mathrm{E}-12$ & $1.052 \mathrm{E}-11$ & $3.831 \mathrm{E}-11$ \\
\hline 12 & $2.129 \mathrm{E}-12$ & 3.619E-12 & 1.717E-14 & 3.425E-14 & 7.395E-14 & $2.926 \mathrm{E}-13$ & 8.275E-13 & $2.396 \mathrm{E}-12$ & $5.274 \mathrm{E}-12$ & $8.463 \mathrm{E}-12$ & $1.130 \mathrm{E}-11$ & $3.828 \mathrm{E}-11$ \\
\hline 13 & $1.962 \mathrm{E}-12$ & $3.408 \mathrm{E}-12$ & $1.505 \mathrm{E}-14$ & 2.929E-14 & $6.096 \mathrm{E}-14$ & $2.515 \mathrm{E}-13$ & $6.670 \mathrm{E}-13$ & $2.095 \mathrm{E}-12$ & $5.876 \mathrm{E}-12$ & 7.902E-12 & $1.140 \mathrm{E}-11$ & 3.303E-11 \\
\hline 14 & $1.772 \mathrm{E}-12$ & 3.113E-12 & $1.284 \mathrm{E}-14$ & $2.502 \mathrm{E}-14$ & $5.701 \mathrm{E}-14$ & $2.152 \mathrm{E}-13$ & $5.748 \mathrm{E}-13$ & $1.889 \mathrm{E}-12$ & $4.820 \mathrm{E}-12$ & 7.567E-12 & $1.042 \mathrm{E}-11$ & $3.118 \mathrm{E}-11$ \\
\hline 15 & $1.614 \mathrm{E}-12$ & $2.884 \mathrm{E}-12$ & $1.224 \mathrm{E}-14$ & $2.194 \mathrm{E}-14$ & $4.861 \mathrm{E}-14$ & $1.835 \mathrm{E}-13$ & $5.303 \mathrm{E}-13$ & $1.711 \mathrm{E}-12$ & $4.208 \mathrm{E}-12$ & 7.193E-12 & $9.471 \mathrm{E}-12$ & $2.213 \mathrm{E}-11$ \\
\hline 16 & $1.411 \mathrm{E}-12$ & $2.631 \mathrm{E}-12$ & 1.140E-14 & $1.689 \mathrm{E}-14$ & 4.397E-14 & $1.612 \mathrm{E}-13$ & $4.660 \mathrm{E}-13$ & $1.495 \mathrm{E}-12$ & $3.622 \mathrm{E}-12$ & $6.014 \mathrm{E}-12$ & $8.348 \mathrm{E}-12$ & $2.328 \mathrm{E}-11$ \\
\hline
\end{tabular}




\begin{tabular}{|c|c|c|c|c|c|c|c|c|c|c|c|c|}
\hline Hour & Average & St. Dev. & Minimum & $2.5 \%$ & $10 \%$ & $25 \%$ & Median & $75 \%$ & $90 \%$ & $95 \%$ & $97.5 \%$ & Maximum \\
\hline 17 & 1.270E-12 & $2.244 \mathrm{E}-12$ & $9.642 \mathrm{E}-15$ & 1.479E-14 & $3.958 \mathrm{E}-14$ & $1.421 \mathrm{E}-13$ & 4.120E-13 & $1.341 \mathrm{E}-12$ & $3.350 \mathrm{E}-12$ & $6.150 \mathrm{E}-12$ & 7.923E-12 & $1.788 \mathrm{E}-11$ \\
\hline 18 & $1.222 \mathrm{E}-12$ & $2.372 \mathrm{E}-12$ & 7.304E-15 & 1.277E-14 & $3.480 \mathrm{E}-14$ & $1.258 \mathrm{E}-13$ & $3.686 \mathrm{E}-13$ & $1.240 \mathrm{E}-12$ & $2.991 \mathrm{E}-12$ & $5.745 \mathrm{E}-12$ & 7.490E-12 & $2.175 E-11$ \\
\hline 19 & $1.182 \mathrm{E}-12$ & $2.378 \mathrm{E}-12$ & $5.718 \mathrm{E}-15$ & $1.308 \mathrm{E}-14$ & $3.340 \mathrm{E}-14$ & $1.112 \mathrm{E}-13$ & $3.411 \mathrm{E}-13$ & $1.093 \mathrm{E}-12$ & $2.791 \mathrm{E}-12$ & $5.616 \mathrm{E}-12$ & $8.131 \mathrm{E}-12$ & $2.093 \mathrm{E}-11$ \\
\hline 20 & $1.163 \mathrm{E}-12$ & $2.680 \mathrm{E}-12$ & 4.966E-15 & $1.206 \mathrm{E}-14$ & $3.015 \mathrm{E}-14$ & $1.021 \mathrm{E}-13$ & $2.975 \mathrm{E}-13$ & $9.750 \mathrm{E}-13$ & $2.550 \mathrm{E}-12$ & $5.001 \mathrm{E}-12$ & 7.906E-12 & $3.104 \mathrm{E}-11$ \\
\hline 21 & $1.025 \mathrm{E}-12$ & $2.142 \mathrm{E}-12$ & 4.417E-15 & $1.013 \mathrm{E}-14$ & $2.651 \mathrm{E}-14$ & $9.053 \mathrm{E}-14$ & $2.704 \mathrm{E}-13$ & $8.889 \mathrm{E}-13$ & $2.331 \mathrm{E}-12$ & 4.763E-12 & 8.069E-12 & $1.959 \mathrm{E}-11$ \\
\hline 22 & $1.018 \mathrm{E}-12$ & $2.333 \mathrm{E}-12$ & 4.607E-15 & $9.587 \mathrm{E}-15$ & $2.514 \mathrm{E}-14$ & $8.086 \mathrm{E}-14$ & $2.535 \mathrm{E}-13$ & $8.218 \mathrm{E}-13$ & $2.158 \mathrm{E}-12$ & 4.679E-12 & $8.336 \mathrm{E}-12$ & $2.214 \mathrm{E}-11$ \\
\hline 23 & $9.374 \mathrm{E}-13$ & 2.237E-12 & 4.922E-15 & $8.335 \mathrm{E}-15$ & $2.477 \mathrm{E}-14$ & 6.877E-14 & $2.319 \mathrm{E}-13$ & 7.412E-13 & $1.956 \mathrm{E}-12$ & $4.464 \mathrm{E}-12$ & 7.319E-12 & $2.476 \mathrm{E}-11$ \\
\hline 24 & 8.957E-13 & $2.431 \mathrm{E}-12$ & 4.037E-15 & $8.126 \mathrm{E}-15$ & $2.274 \mathrm{E}-14$ & 6.697E-14 & $2.190 \mathrm{E}-13$ & 6.667E-13 & $1.896 \mathrm{E}-12$ & $4.385 \mathrm{E}-12$ & $6.078 \mathrm{E}-12$ & $3.168 \mathrm{E}-11$ \\
\hline 25 & $8.261 \mathrm{E}-13$ & $2.326 \mathrm{E}-12$ & $3.435 \mathrm{E}-15$ & $8.139 E-15$ & $2.138 \mathrm{E}-14$ & 6.057E-14 & $2.043 \mathrm{E}-13$ & $6.049 \mathrm{E}-13$ & $1.830 \mathrm{E}-12$ & $3.841 \mathrm{E}-12$ & $6.264 \mathrm{E}-12$ & $3.160 \mathrm{E}-11$ \\
\hline 26 & 7.509E-13 & $2.119 \mathrm{E}-12$ & $3.258 \mathrm{E}-15$ & 7.648E-15 & $1.925 \mathrm{E}-14$ & 5.307E-14 & $1.885 \mathrm{E}-13$ & $5.454 \mathrm{E}-13$ & $1.602 \mathrm{E}-12$ & $3.234 \mathrm{E}-12$ & 5.594E-12 & $2.919 \mathrm{E}-11$ \\
\hline 27 & 6.747E-13 & $2.000 \mathrm{E}-12$ & $3.260 \mathrm{E}-15$ & $7.258 \mathrm{E}-15$ & $1.811 \mathrm{E}-14$ & 4.597E-14 & $1.719 \mathrm{E}-13$ & $5.093 \mathrm{E}-13$ & $1.409 \mathrm{E}-12$ & $2.853 \mathrm{E}-12$ & $4.809 \mathrm{E}-12$ & 3.055E-11 \\
\hline 28 & $5.535 \mathrm{E}-13$ & $1.193 \mathrm{E}-12$ & $3.180 \mathrm{E}-15$ & $6.725 \mathrm{E}-15$ & $1.705 \mathrm{E}-14$ & $4.343 \mathrm{E}-14$ & $1.613 \mathrm{E}-13$ & $4.648 \mathrm{E}-13$ & $1.312 \mathrm{E}-12$ & $2.425 \mathrm{E}-12$ & $3.729 \mathrm{E}-12$ & $1.165 \mathrm{E}-11$ \\
\hline 29 & 4.930E-13 & 1.097E-12 & $3.025 \mathrm{E}-15$ & $6.538 \mathrm{E}-15$ & $1.622 \mathrm{E}-14$ & $4.008 \mathrm{E}-14$ & $1.453 \mathrm{E}-13$ & $4.430 \mathrm{E}-13$ & $1.196 \mathrm{E}-12$ & $2.082 \mathrm{E}-12$ & 3.550E-12 & $1.217 \mathrm{E}-11$ \\
\hline 30 & $4.430 \mathrm{E}-13$ & $9.310 \mathrm{E}-13$ & $2.720 \mathrm{E}-15$ & $6.209 E-15$ & $1.454 \mathrm{E}-14$ & $3.664 \mathrm{E}-14$ & $1.335 \mathrm{E}-13$ & $4.114 \mathrm{E}-13$ & $1.079 \mathrm{E}-12$ & $1.830 \mathrm{E}-12$ & $3.040 \mathrm{E}-12$ & $7.036 \mathrm{E}-12$ \\
\hline 31 & 4.243E-13 & 9.917E-13 & $2.577 \mathrm{E}-15$ & 5.593E-15 & $1.331 \mathrm{E}-14$ & 3.353E-14 & $1.268 \mathrm{E}-13$ & $3.786 \mathrm{E}-13$ & $1.001 \mathrm{E}-12$ & 1.709E-12 & $2.674 \mathrm{E}-12$ & $9.175 \mathrm{E}-12$ \\
\hline 32 & 4.023E-13 & $9.608 \mathrm{E}-13$ & $2.238 \mathrm{E}-15$ & 5.309E-15 & $1.208 \mathrm{E}-14$ & $3.118 \mathrm{E}-14$ & $1.152 \mathrm{E}-13$ & $3.584 \mathrm{E}-13$ & 8.997E-13 & 1.577E-12 & $3.251 \mathrm{E}-12$ & $7.658 \mathrm{E}-12$ \\
\hline 33 & $3.670 \mathrm{E}-13$ & $8.595 \mathrm{E}-13$ & $1.738 \mathrm{E}-15$ & 4.980E-15 & $1.134 \mathrm{E}-14$ & $2.907 \mathrm{E}-14$ & $1.055 \mathrm{E}-13$ & $3.214 \mathrm{E}-13$ & $7.755 \mathrm{E}-13$ & $1.539 \mathrm{E}-12$ & $2.799 \mathrm{E}-12$ & $7.008 \mathrm{E}-12$ \\
\hline 34 & 3.330E-13 & 7.432E-13 & $1.303 \mathrm{E}-15$ & 4.822E-15 & 1.029E-14 & $2.879 \mathrm{E}-14$ & $9.663 \mathrm{E}-14$ & $3.018 \mathrm{E}-13$ & $7.130 \mathrm{E}-13$ & $1.339 \mathrm{E}-12$ & $2.623 \mathrm{E}-12$ & 5.893E-12 \\
\hline
\end{tabular}


PNNL-23176

\begin{tabular}{|c|c|c|c|c|c|c|c|c|c|c|c|c|}
\hline Hour & Average & St. Dev. & Minimum & $2.5 \%$ & $10 \%$ & $25 \%$ & Median & $75 \%$ & $90 \%$ & $95 \%$ & $97.5 \%$ & Maximum \\
\hline 35 & $2.965 \mathrm{E}-13$ & $6.224 \mathrm{E}-13$ & $9.968 \mathrm{E}-16$ & $4.251 \mathrm{E}-15$ & $9.507 \mathrm{E}-15$ & $2.687 \mathrm{E}-14$ & $8.928 \mathrm{E}-14$ & $2.774 \mathrm{E}-13$ & $6.823 \mathrm{E}-13$ & $1.273 \mathrm{E}-12$ & $2.228 \mathrm{E}-12$ & $5.104 \mathrm{E}-12$ \\
\hline 36 & $2.769 \mathrm{E}-13$ & $5.815 \mathrm{E}-13$ & $7.799 \mathrm{E}-16$ & $4.020 \mathrm{E}-15$ & $9.133 \mathrm{E}-15$ & $2.413 \mathrm{E}-14$ & 8.217E-14 & $2.518 \mathrm{E}-13$ & $6.695 \mathrm{E}-13$ & $1.174 \mathrm{E}-12$ & $1.846 \mathrm{E}-12$ & $5.234 \mathrm{E}-12$ \\
\hline 37 & $2.612 \mathrm{E}-13$ & $5.711 \mathrm{E}-13$ & $6.700 \mathrm{E}-16$ & 4.185E-15 & $8.819 \mathrm{E}-15$ & $2.327 \mathrm{E}-14$ & 7.662E-14 & $2.553 \mathrm{E}-13$ & $6.272 \mathrm{E}-13$ & $1.165 \mathrm{E}-12$ & $1.649 \mathrm{E}-12$ & $6.452 \mathrm{E}-12$ \\
\hline 38 & $2.435 \mathrm{E}-13$ & $5.521 \mathrm{E}-13$ & $6.927 \mathrm{E}-16$ & $3.960 \mathrm{E}-15$ & $8.459 \mathrm{E}-15$ & $2.176 \mathrm{E}-14$ & $7.611 \mathrm{E}-14$ & $2.212 \mathrm{E}-13$ & $5.989 \mathrm{E}-13$ & $9.935 \mathrm{E}-13$ & $1.317 \mathrm{E}-12$ & $7.086 \mathrm{E}-12$ \\
\hline 39 & $2.301 \mathrm{E}-13$ & $5.186 \mathrm{E}-13$ & $6.145 \mathrm{E}-16$ & $3.706 \mathrm{E}-15$ & $7.976 \mathrm{E}-15$ & $2.078 \mathrm{E}-14$ & $7.139 \mathrm{E}-14$ & $2.116 \mathrm{E}-13$ & $5.629 \mathrm{E}-13$ & $9.859 \mathrm{E}-13$ & $1.278 \mathrm{E}-12$ & $6.293 \mathrm{E}-12$ \\
\hline 40 & $2.184 \mathrm{E}-13$ & $4.968 \mathrm{E}-13$ & $6.551 \mathrm{E}-16$ & $3.239 \mathrm{E}-15$ & $7.431 \mathrm{E}-15$ & $1.947 \mathrm{E}-14$ & $6.666 \mathrm{E}-14$ & $1.934 \mathrm{E}-13$ & $5.215 \mathrm{E}-13$ & $9.420 \mathrm{E}-13$ & $1.193 \mathrm{E}-12$ & $5.885 \mathrm{E}-12$ \\
\hline 41 & $2.120 \mathrm{E}-13$ & $5.531 \mathrm{E}-13$ & $7.998 \mathrm{E}-16$ & $3.075 \mathrm{E}-15$ & $7.411 \mathrm{E}-15$ & $1.927 \mathrm{E}-14$ & $6.113 \mathrm{E}-14$ & $1.814 \mathrm{E}-13$ & $4.885 \mathrm{E}-13$ & 8.792E-13 & $1.261 \mathrm{E}-12$ & 8.084E-12 \\
\hline 42 & $2.088 \mathrm{E}-13$ & $5.560 \mathrm{E}-13$ & $1.043 \mathrm{E}-15$ & $2.709 \mathrm{E}-15$ & $7.028 \mathrm{E}-15$ & $1.744 \mathrm{E}-14$ & $5.778 \mathrm{E}-14$ & $1.720 \mathrm{E}-13$ & 4.747E-13 & 8.753E-13 & $1.376 \mathrm{E}-12$ & 8.249E-12 \\
\hline 43 & $1.979 \mathrm{E}-13$ & 5.309E-13 & $1.325 \mathrm{E}-15$ & $2.537 \mathrm{E}-15$ & $6.405 E-15$ & $1.612 \mathrm{E}-14$ & 5.501E-14 & $1.667 \mathrm{E}-13$ & $4.214 \mathrm{E}-13$ & 7.753E-13 & $1.203 \mathrm{E}-12$ & $7.960 \mathrm{E}-12$ \\
\hline 44 & $1.908 \mathrm{E}-13$ & $5.162 \mathrm{E}-13$ & $1.222 \mathrm{E}-15$ & $2.386 \mathrm{E}-15$ & $5.872 \mathrm{E}-15$ & $1.569 \mathrm{E}-14$ & $5.176 \mathrm{E}-14$ & $1.483 \mathrm{E}-13$ & $4.146 \mathrm{E}-13$ & $7.463 \mathrm{E}-13$ & $1.441 \mathrm{E}-12$ & $7.571 \mathrm{E}-12$ \\
\hline 45 & $1.825 \mathrm{E}-13$ & $4.945 \mathrm{E}-13$ & $1.212 \mathrm{E}-15$ & $2.210 \mathrm{E}-15$ & $5.784 \mathrm{E}-15$ & $1.476 \mathrm{E}-14$ & $4.931 \mathrm{E}-14$ & $1.384 \mathrm{E}-13$ & $4.050 \mathrm{E}-13$ & 7.619E-13 & $1.269 \mathrm{E}-12$ & $7.080 \mathrm{E}-12$ \\
\hline 46 & $1.675 \mathrm{E}-13$ & $4.409 E-13$ & $1.149 \mathrm{E}-15$ & $2.301 \mathrm{E}-15$ & $5.685 \mathrm{E}-15$ & $1.412 \mathrm{E}-14$ & $4.568 \mathrm{E}-14$ & $1.361 \mathrm{E}-13$ & 3.796E-13 & $7.128 \mathrm{E}-13$ & $1.057 \mathrm{E}-12$ & $6.221 \mathrm{E}-12$ \\
\hline 47 & $1.606 \mathrm{E}-13$ & 4.197E-13 & $1.090 \mathrm{E}-15$ & $2.227 \mathrm{E}-15$ & $5.464 \mathrm{E}-15$ & $1.361 \mathrm{E}-14$ & $4.232 \mathrm{E}-14$ & $1.269 \mathrm{E}-13$ & $3.657 \mathrm{E}-13$ & $6.520 \mathrm{E}-13$ & $1.140 \mathrm{E}-12$ & $5.809 \mathrm{E}-12$ \\
\hline 48 & $1.509 \mathrm{E}-13$ & $3.869 \mathrm{E}-13$ & $1.059 \mathrm{E}-15$ & $2.272 \mathrm{E}-15$ & $5.237 \mathrm{E}-15$ & $1.220 \mathrm{E}-14$ & 3.971E-14 & $1.189 \mathrm{E}-13$ & $3.852 \mathrm{E}-13$ & $6.342 \mathrm{E}-13$ & $1.118 \mathrm{E}-12$ & $5.292 \mathrm{E}-12$ \\
\hline
\end{tabular}




\subsection{Conclusions}

Atmospheric transport modeling was used to estimate the effective dilution factors for non-decaying, non-depositing tracers after a release occurring at 2,500 m AGL. This work examined the dilution factors in the time period from 4 to 48 hours after the release. A power law relationship can be used to describe the median dilution factors based on releases on any day over an entire year. Although the dilution factors vary significantly based on the day of release, about $95 \%$ of them are within an order of magnitude of the median value. A slight modification of the power law relationship for the median non-decaying, non-depositing tracer provides a simple relationship for isotopes with varying half-lives.

Although it is tempting to apply this trend-line to all potential release locations, modeling cases conducted for other activities suggest that trend lines for different release locations can vary substantially. Further work is needed to develop a suite of dilution-factor relationships applicable to an arbitrary release location. 
PNNL-23176

\subsection{References}

Draxler, RR, and GD Hess. 1998. "An Overview of the HYSPLIT_4 Modeling System of Trajectories, Dispersion, and Deposition." Aust. Meteor. Mag. 47:295-308.

Draxler, RR, B Stunder, G Rolph, A Stein, and A Taylor. 2013. HYSPLIT4 User's Guide, Version 4., Air Resources Laboratory, National Oceanic and Atmospheric Administration (NOAA), Silver Spring, MD.

http://www.arl.noaa.gov/documents/reports/hysplit_user_guide.pdf.

Firestone, RB. 2014. The Berkeley Laboratory Isotopes Project's Exploring the Table of Isotopes. Ernest O. Lawrence Berkeley National Laboratory. Accessed on January 31, 2014, at http://ie.lbl.gov/education/isotopes.htm (last updated May 22, 2000).

GDAS. 2012. Global Data Assimilation System Archive. Air Resources Laboratory, National Oceanic and Atmospheric Administration. Accessed on April 2, 2012, at ftp://arlftp.arlhq.noaa.gov/pub/archives/gdas1/ 


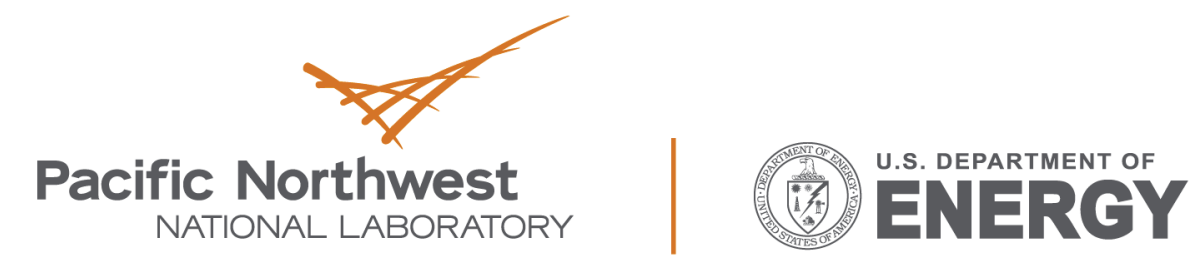

Proudly Operated by Battelle Since 1965

902 Battelle Boulevard

P.O. Box 999

Richland, WA 99352

1-888-375-PNNL (7665)

www.pnnl.gov 